\title{
KEMANDIRIAN LANJUT USIA DALAM AKTIFITAS SEHARI-HARI DI WILAYAH KERJA PUSKESMAS NUSA INDAH BENGKULU
}

\author{
Ederly Independence in tha Nusa Indah Health Center Bengkulu \\ Rosa Aria $^{1}$, Ikhsan $^{2}$, Nurlaily $^{3}$ \\ Program Studi Keperawatan FMIPA Universitas Bengkulu \\ Email : ikhsan@unib.ac.id
}

\begin{abstract}
ABSTRAK
Tahap akhir proses penuaan pada pertumbuhan dan perkembangan manusia merupakan istilah dari lanjut usia. Lanjut usia (Lansia) adalah seseorang yang telah memasuki usia 60 tahun. Lansia mandiri adalah lansia dalam kondisi mampu untuk menjalankan kehidupan pribadinya. Tujuan dari penelitian ini yaitu untuk mengetahui tentang Gambaran Kemandirian Lansia Dalam Aktivitas Sehari-hari Di Wilayah Kerja Puskesmas Nusa Indah Kota Bengkulu. Desain yang digunakan dalam penelitian ini adalah deskriptif dengan sampel 50 lansia dengan tekniik pusposive sampling Di Wilayah Kerja Puskesmas Nusa Indah Kota Bengkulu alat pengumpulan data yang digunakan yaitu kuisoner Barthel index. Data diolah dengan deksriptif persentase, dari 50 responden di Wilayah Kerja Puskesmas Nusa Indah Kota Bengkulu, mayoritas paling banyak yaitu lansia berjenis kelamin perempuan dengan jumlah 33 lansia (66\%). Terdapat 47 responden $(94 \%)$ lansia mempunyai tingkat kemandirian yang mandiri, sedangkan 3 responden (6\%) dikatakan tidak mandiri. Hal ini disebabkan karena beberapa faktor diantaranya status perkembangan, kondisi kesehatan, kondisi ekonomi, dan kondisi sosial yang baik.Hasil penelitian ini diharapkan dapat digunakan sebagai acuan dalam melakukan penelitian selanjutnya, diantaranya penelitian yang dapat dihubungkan dengan faktor-faktor yang mempengaruhi kemandirian lansia serta pentingnya terkait dukungan keluarga dalam memberikan motivasi kepada lansia.
\end{abstract}

Kata Kunci : Tingkat Kemandirian, Lansia 


\begin{abstract}
The aging process of human growth and development is the term of the elderly. Seniors (Elderly) is someone who has entered the age of 60 years. elderly in a condition capable of running his personal life. The purpose of this study is to find out about the Independence of the Elderly Independence in Daily Activities In Health Center Nusa Indah Bengkulu City. The design used in this study is descriptive with a sample of 50 elderly In Puskesmas Nusa Indah Kota Bengkulu data collection tool used is the quizoner Barthel index with purposive sampling technique. The results showed that of the 50 respondents in the work area of Nusa Indah Public Health Center of Bengkulu City, the majority of women are elderly with total number of 33 elderly (66\%). There are 47 respondents $(94 \%)$ elderly have independent level of independence, while 3 respondents $(6 \%)$ said not independent. This is due to several factors including the status of development, health conditions, economic conditions, and good social conditions. The results of this study is expected to be used as a reference in conducting further research, including research that can be associated with factors that affect the independence of the elderly as well as the importance related to family support in providing motivation to the elderly.
\end{abstract}

Key Words : The Level of Independence, Elderly 
Lanjut usia (Lansia)Menurut UU Kesehatan NO 36 Tahun 2009 adalah seseorang yang karena usianya yang lanjut mengalami perubahan biologis, fisik, kejiwaan, dan sosial. Perubahan ini akan memberikan pengaruh pada seluruh aspek kehidupan, termasuk kesehatannya. Kesehatan manusia lanjut usia perlu mendapat perhatian khusus dengan tetap dipelihara dan tingkatkan agar selama mungkin dapat hidup secara produktif sesuai dengan kemampuannya sehingga dapat ikut serta berperan aktif dalam pembangunan.

Menurut constantinindes, menua atau menjadi tua adalah suatu proses menghilangnya secara perlahan-lahan kemampuan jaringan untuk memperbaiki diri/mengganti dan mempertahankan fungsi normalnya sehingga tidak dapat bertahan terhadap infeksi dan memperbaiki kerusakan yang diderita. Proses menua merupakan proses yang terus menerus secara alamiah. Dimulai sejak lahir dan umumnya dialami pada semua makhluk hidup. Semua orang akan mengalami proses menjadi tua dan masa tua merupakan masa hidup manusia yang terakhir yang pada masa ini seseorang mengalami kemunduran fisik, mental, fan sosial sedikit demi sedikit sampai tidak dapat melakukan tugasnya seharihari lagi sehingga bagi kebanyakan orang, masa tua merupakan masa yang kurang menyenangkan (Nugroho, 2010 dalam Murwani dan Priyantari 2011).

Berdasarkan data yang dikeluarkan oleh Badan Kesehatan
Dunia (WHO) pada tahun 2013 proporsi dari populasi penduduk berusia lebih dari 60 tahun adalah $11,7 \%$ dari total populasi dunia dan diperkirakan jumlah tersebut akan terus meningkat seiring dengan peningkatan usia harapan hidup. Badan kesehatan dunia (WHO) juga menunjukan bahwa penduduk lansia di Indonesia pada tahun 2020 mendatang sudah mencapai angka $11,34 \%$ atau tercatat 28,8 juta orang. Pada tahun 2015 jumlah lanjut usia (lansia) di Provinsi Bengkulu yaitu berjumlah 80.993 jiwa terdiri dari laki laki 37.454 jiwa dan perempuan 43.539 jiwa dengan presentase 6,5 \% (Dinkes Prov Bengkulu, 2015) dibandingkan dengan provinsi kalimantan utara yang memiliki jumlah lansia dengan presentase 5,3 \% dapat dikatakan provinsi bengkulu memiliki jumlah lansia yang cukup besar. (Kemenkes RI, 2015).

Lanjut usia adalah suatu keadaan yang terjadi kemunduran, seperti kemunduran fisik yang ditandai dengan perubahan kulit yang mengerut, rambut memutih, gigi yang tidak utuh (ompong), pendengaran tidak jelas, penglihatan semakin memburuk, penurunan keseimbangan tubuh, gangguan peredarahn darah, pergerakannya menjadi lambat, dan gerakan tubuh yang tidak proporsional(Nugroho, 2008).

Graf (2008),penyakit akut atau kondisi kronis akan memburuk dan dapat mempercepat penurunkan fungsional dan ini dapat menurunkan kemampuanlansia untuk melakukan 
kegiatan penting hidup mandirinya mengenaiActivity of DailyLiving (ADL). Kemandirian lansia dapat dipengaruhi oleh pendidikan lansia, fungsikognitif yang menurun, gangguan sensori khususnya penglihatan dan pendengaran (Heryanti, 2011).

Salah satu bentuk untuk mengukur kemampuan seseorang dalam melakukan kegiatan seharihari adalah mengkaji Activity of Daily Living (ADL) lansia. Maka dari itu pengkajian status fungsional sangat penting, terutama ketika terjadi hambatan pada kemampuan lansia dalam melaksanakan fungsi kehidupan sehari-harinya. Aktivitas kehidupan harian (Activity of DailyLiving) adalah merupakan aktivitas pokok bagi perawatan diri. ADL meliputi antaralain: ke toilet, makan, berpakaian (berdandan), mandi, dan berpindah tempat. Penentuan kemandirian fungsional dilakukan untuk mengidentifikasi kemampuan dan keterbatasan klien, serta menciptakan pemilihan intervensi yang tepat. (Kushariadi, 2009).

Kemandirian mempengaruhi perubahan situasi kehidupan, aturan sosial, usia dan penyakit. Lansia akan berangsur-angsur mengalami keterbatasan dalam kemampuan fisik dan peningkatan kerentanan terhadap penyakit kronis. Kemandirian Lansia di pengaruhi olehfaktor usia dan imobilitas. Faktor pertama yang mempengaruhi tingkat kemandirian lansia yang menentukan tingkat kemandirian lansia yaitu usia, usia yang semakin bertambah membuat lansia kesulitan untuk memenuhi kebutuhan sehari-hari.Semakin usia lansia bertambah semakin pula aktivitas lansia menurun. Imobilitas merupakan ketidakmampuan lansia untuk bergerak secara aktif akibat penyakit misalnya lansia tidak mampu bergerak secara aktif akibat penyakit stroke, artinya bila seseorang bertambah tuakemampuan fisik dan mentalnya perlahan akan menurun. Kemampuan fisik dan mental yang menurun sering menyebabkan jatuh pada lansia, akibatnya akan berdampak pada menurunnya aktivitas dalam kemandirian lansia.Ketergantungan lanjut usia disebabkan kondisi lansia banyak mengalami kemunduran fisik maupun psikis. Sedangkan bila dilihat dari tingkat ketergantungan lansia dalam hal ekonomi membuat gerak lansia menjadi terbatas baik secara fisik maupun mental.

Data Dinkes Kota Bengkulu tahun 2016 cakupan data pelayanan kesehatan lanjut usia menurut jenis kelamin di wilayah puskesmas Nusa Indah kota bengkulu yaitu yang berjumlah 528 laki-laki dan 577 perempuan jumlah keseluruhan 1.105 lanjut usia. Lansia yang mendapatkan pelayanan kesehatan yang berjenis kelamin laki-laki 248 $(46,97 \%)$ dan perempuan 480 $(83,19 \%)$. Jadi jumlah lansia keseluruhan antara lansia laki-laki dan perempuan yang mendapatkan pelayanan kesehatan di tahun 2016 berjumlah 728(65,88\%).

Hasil survey pendahuluan yang di lakukan terhadap lansia tentang gambaran kemandirian lansia dari 10 lansia yang di wawancarai 7 (70\%) lansia mengalami ketergantungan dalam aktivitas sehari-hari dan 3 (30\%) lansia yang masih mandiri. Oleh karena itu, 
peneliti tertarik melakukan penelitian tentang gambaran kemandirian lansia dalam aktivitas sehari-hari. Khulaifah, dkk (2014) mendapatkan gambaran kemandirian lasia di Dusun Sumbayat Timur Gresik hanya $41,2 \%$ mandiri dan selebinya mengalami ketergantingan mulai dari ringan sampai total.

Rumusan masalah adalah bagaimanakah gambaran gambaran kemandirian lansia dalam aktivitas sehari-hari di wilayah kerja puskesmas Nusa Indah Kota Bengkulu.. Adapun tujuan penelitian untuk mengetahui gambaran kemandirian lansia dalam aktivitas sehari-hari di wilayah kerja puskesmas Nusa ota Bengkulu.

\section{A. Metodologi}

Jenis penelitian ini adalah penelitian deskriptif kuantitatif dengan subjek lansia di

\section{B. Hasil Penelitian}

1. Usia
Puskesmas Nusa Indah. Desain penelitiaan deskriptif, untuk mendeskripsikan tentang tingkat kemandirian dan ketergantungan lanjut usia dalam pemenuhan aktivitas sehari-Hari. Sampel 50 lansia dengan teknik pengambilan sample purposive sampling atau jugement sampling merupakan suatu teknik penetapan sampel dengan cara memilih sample di antara populasi sesuai yang dikendaki oleh peneliti. Pengumpulan data dilakukan dengan menggunakan kuisioner dengan memberikan kuisioner kepada responden. Analisa data yang dilakukan oleh peneliti adalah analisa deskriptif yaitu suatu prosedur pengolahan data dengan menggambarkan dan meringkas data dengan cara ilmiah dalam bentuk tabel.

Tabel 1. Distribusi Karakteristik Responden Berdasarkan Usia pada Lansia Puskesmas Nusa Indah Kota Bengkulu

\begin{tabular}{ccc}
\hline $\begin{array}{c}\text { Karakteristik Berdasarkan Usia Pada } \\
\text { Lansia }\end{array}$ & Frekuensi & Persentase \\
\hline 60-74 Tahun & 38 & $76 \%$ \\
$75-90$ Tahun & 12 & $24 \%$ \\
\hline Total & 50 & $100 \%$
\end{tabular}

Berdasarkan Tabel 1 diatas menjelaskan bahwa sebagian besar responden berusia 60-74 tahun sebanyak 38 responden (76\%). 
2. Jenis Kelamin

Tabel 2. Distribusi Karakteristik Responden Berdasarkan Jenis Kelamin pada Lansia Puskesmas Nusa Indah Kota Bengkulu

Jenis Kelamin

Frekuensi

Persentase

\begin{tabular}{ccc}
\hline Laki-laki & 17 & $34 \%$ \\
Perempuan & 33 & $66 \%$ \\
\hline Total & 50 & $100 \%$
\end{tabular}

Berdasarkan Tabel 2 diatas menjelaskan bahwa lebih dari setengah responden berjenis kelamin perempuan sebanyak 33 responden ( 66\%).

3. Pendidikan

Tabel 3. Distribusi Karakteristik Responden Berdasarkan Pendidikan pada Lansia Puskesmas Nusa Indah Kota Bengkulu

\begin{tabular}{ccc}
\hline Pendidikan Pada Lansia & Frekuensi & Persentase \\
\hline Tidak Sekolah & 4 & $8 \%$ \\
SD & 17 & $34 \%$ \\
SMP & 7 & $14 \%$ \\
SMA & 10 & $20 \%$ \\
Perguruan tinggi & 12 & $24 \%$ \\
\hline Total & 50 & $100 \%$
\end{tabular}

Berdasarkan Tabel 3 diatas menjelaskan bahwa sebagian kecil responden tidak sekolah sebanyak 4 responden $(8 \%)$. 


\section{Tempat Tinggal}

Tabel 4. Distribusi Karakteristik Responden Berdasarkan Tempat Tinggal pada LansiaPuskesmas Nusa Indah Kota Bengkulu

\begin{tabular}{ccc}
\hline $\begin{array}{c}\text { Karakteristik Berdasarkan } \\
\text { Tempat Tinggal Pada Lansia }\end{array}$ & Frekuensi & Persentase \\
\hline Rumah Sendiri & 16 & $32 \%$ \\
Tinggal Bersama Pasangan & 12 & $24 \%$ \\
Tinggal dengan anak & 22 & $44 \%$ \\
\hline Total & 50 & $100 \%$
\end{tabular}

Berdasarkan Tabel 4 diatas menjelaskan bahwa hampir setengah responden yang tinggal dengan anaknya sebanyak 22 responden (44\%).

1. Tingkat Kemandirian lansia

Tabel 5. Distribusi Frekuensi Tingkat Kemandirian Pada Lansia Puskesmas Nusa Indah Kota Bengkulu

\begin{tabular}{ccc}
\hline Tingkat & Frekuensi & Persentase \\
\hline Mandiri & 47 & $94 \%$ \\
Ketergantungan & 3 & $6 \%$ \\
\hline Total & 50 & $100 \%$ \\
\hline
\end{tabular}

Berdasarkan Tabel 5 diatas menjelaskan bahwa hampir seluruh responden yang mandiri sebanyak 47 responden (94\%).

C. Pembahasan

Berdasarkan hasil pengukuran tingkat kemandirian lansia dalam Activity of DailyLiving di Wilayah Kerja Puskesmas Nusa Indah dengan menggunakan Barthel indeks menunjukanbahwa hampir seluruh responden memiliki tingkat kemandirian yaitu 94\%. Tingkat kemandirian tersebut disebabkan karena adanya faktor kesehatan, fungsi motorik, fungsi kognitif dan status perkembangan yang baik pada lansia sehingga lanjut usia masih dapat melakukan aktifitas sehariharinya sendiri tanpa batuan orang lain. Berdasarkan observasi peneliti banyak ditemukan lansia tetap memaksa untuk memenuhi Activity of Daily Living secara mandiri misalnya berusaha mandiri untuk 
pergi ke toilet walaupun kemampuan berjalan sudah berkurang. Pada beberapa lansia juga, mereka berusaha untuk makan secara mandiri walaupun mereka sudah kurang mampu memasukan makanan ke dalam mulut karena penyakit yang diderita atau kelemahan yang dimilikinya (Ediawati Eka, 2012). Dari hasil penelitian bahwa dari 50 responden, 12 responden (24\%) usia 75-90 tahun lebih berisiko dibandingkan responden berusia 60 74 tahun.

Dari segi jenis kelamin wanita lebih mandiri dibanding lakilaki, sejalan dengan penelitian Indah Sampelan, dkk (2015) yang juga menyatakan bahwa dalam penelitiannya responden berjenis kelamin perempuan lebih banyak dibandingkan dengan responden lakilaki. Hal ini didukung dengan hasil Susenas tahun 2009 yang menyatakan bahwa jumlah lansia perempuan lebih banyak, yaitu 10,44 juta $(8,96 \%)$ dibandingkan lansia laki-laki, yaitu 8,88 juta $(7,76 \%)$ (Ediawati Eka, 2012). Dari hasil penelitian responden berjenis kelamin perempuan terdiri dari 33 responden (66\%) lebih banyak dibandingkan responden berjenis kelamin laki-laki yang terdiri dari 17 responden (34\%). Dari segi pendidikan, lansia mandiri berpendidikan tinggi (44\%) di ketahui bahwa tidak terdapat hubungan antara pendidikan dengan kemandirian lansia.

Menurut Komnas lansia (2009) dimana pendidikan merupakan salah satu unsur penting untuk meningkatkan kemampuan masyarakat dalam mencapai kehidupan yang lebih baik. Dengan pendidikan yang semakin tinggi dapat menghasilkan keadaan sosioekonomi makin baik dan kemandirian yang semakin baik. Dari segi tempat tinggal, lansia yang tinggal dirumah sendiri cenderung lebih mandiri dibandingkan dengan lansia yang tinggal bersama anak, dari penelitian ini bisa dilihat lansia yang ketergantungan (6\%) tinggal bersama anaknya, sedangkan lansia yang tinggal bersama pasangan terdiri dari 12 responden (24\%) dan lansia yang tinggal dirumah sendiri terdiri dari 16 responden (32\%) bisa dilihat bahwa lansia yang tinggal dirumah sendiri dan tinggal bersama pasangan lebih mandiri dibandingkan lansia yang tinggal bersama anaknya

\section{Kesimpulan}

Berdasarkan hasil penelitian dan pembahasan dapat disimpulkan gambaran kemandirian lanjut usia dalam aktivitas sehari-hari Di Wilayah Kerja Puskesmas Nusa Indah Kota Bengkulu hampir seluruh responden mandiri (94\%).

\section{DAFTAR PUSTAKA}

Azizah, lilik mariatul. 2011. Keperawatan lanjut usia. Yogyakarta: Graha ilmu

Dinkes Kota Bengkulu 2016. Cakupan pelayanan kesehatan usia lanjut menurut jenis kelamin kecamatan dan puskesmas Kota Bengkulu 
Efendi,FerryMakhfudli

KeperawatanKomunitas:Teo ridanPraktik

dalamKeperawatan. Jakarta : Salemba Medika.

Ediawati, Eka. 2013. Gambaran

Tingkat Kemandirian Dalam Actuvity Of Daily Living (ADL).

Heryanti, IP. 2011. Hubungan Kemandirian dan Dukungan Sosial dengan Tingkat Stress Lansia. Bogor : Jurusan Ekologi Manusia Fakultas Pertanian Institut Pertanian Bogor. Tersedia dari http://www.repository.ipb.ac.i d/ . Diakses tanggal 22 maret 201820.00 wib.

Husain, Salindra.2013. Hubungan Dukungan Keluarga Dengan Kemandirian Lansia Dalam Pemenuhan Aktivitas Sehari - hari

Hardywinoto. 2007. Panduan Gerontologi. Jakarta: Pustaka Utama. Kushariyadi. 2009 . Asuhan Keperawatan Klien Lanjut Usia. Jakarta: Salemba Medika.

Maryam. 2011. Mengenal Usia Lanjut dan
Perawatannya. Jakarta: Salemba Medika.

Martono\& Pranarka. 2009. Buku Ajar Geriatri (Ilmu Kesehatan Usia Lanjut). FKUI: Jakarta.

Nugroho, W. 2008. Gerontik dan Geriatrik. Jakarta: Penerbit Buku Kedokteran EGC.

Nursalam. 2013.Konsep Penerapan Metode Penelitian Ilmu Keperawatan. Jakarta: Salemba Medika.

Riskesdas.2014. Riset kesehatandasar.jakarta.bad an penelitian danpengembangan kesehatan kementerian kesehatan Ri.

Yuliatri, Eka, dkk.Hubungan Tingkat Depresi Dengan TingkatKemandiriandalanAkt ivitasSehari-hari pada Lansia di Wilayah PuskesmasTembilahanHulu,2 014file

http://jks.fikes.unsoed.ac.id/ index.php/jks/article/viewFi le/576/316. [LastAccess : 20 maret 2018 jam 19.10 wib 